\title{
MDH2 wt Allele
}

National Cancer Institute

\section{Source}

National Cancer Institute. MDH2 wt Allele. NCI Thesaurus. Code C124984.

Human MDH2 wild-type allele is located within 7cen-q22 and is approximately $19 \mathrm{~kb}$ in length. This allele, which encodes malate dehydrogenase, mitochondrial protein, is involved in the metabolism of malate and the synthesis of oxaloacetate. 